\title{
Exercise and Mental Health: Many Reasons to Move
}

\author{
Andréa Deslandes ${ }^{a}$ Helena Moraes $^{b}$ Camila Ferreira $^{c}$ Heloisa Veiga ${ }^{c}$ \\ Heitor Silveira $^{b}$ Raphael Mouta $^{b}$ Fernando A.M.S. Pompeu ${ }^{d}$ \\ Evandro Silva Freire Coutinho ${ }^{a}$ Jerson Laks ${ }^{b}$ \\ ${ }^{a}$ National School of Public Health, ${ }^{\mathrm{b} C e n t e r}$ for Alzheimer Disease and Related Disorders, and ${ }^{\mathrm{C} B r a i n}$ Mapping \\ and Sensorimotor Integration Laboratory, Institute of Psychiatry, Universidade Federal do Rio de Janeiro, and \\ 'Universidade Federal do Rio de Janeiro, Rio de Janeiro, Brazil
}

\section{Key Words}

Physical activity • Major depression · Alzheimer's disease • Parkinson's disease, elderly

\begin{abstract}
The relationship between physical activity and mental health has been widely investigated, and several hypotheses have been formulated about it. Specifically, during the aging process, physical exercise might represent a potential adjunctive treatment for neuropsychiatric disorders and cognitive impairment, helping delay the onset of neurodegenerative processes. Even though exercise itself might act as a stressor, it has been demonstrated that it reduces the harmful effects of other stressors when performed at moderate intensities. Neurotransmitter release, neurotrophic factor and neurogenesis, and cerebral blood flow alteration are some of the concepts involved. In this review, the potential effects of exercise on the aging process and on mental health are discussed, concerning some of the recent findings on animal and human research. The overwhelming evidence present in the literature today suggests that exercise ensures successful brain functioning.

Copyright $\odot 2009$ S. Karger AG, Basel
\end{abstract}

\section{Introduction}

Neurodegenerative diseases become more prevalent as individuals age and, therefore, represent a serious issue for the healthcare system. Since inactivity is the number one risk factor for many diseases, physical activity has become an emerging topic of interest for many investigators. Exercise might act as an efficient and low-cost adjunctive factor in the treatment and prevention of age-related neurodegenerative processes $[1,2]$. Recent studies have focused on the correlation between physical activity and mental health [3-6]. Clinical evidence has demonstrated that exercise has a positive relationship with the outcome of different mental diseases, such as depression, Alzheimer's disease and Parkinson's disease, improving not only patients' quality of life but the disease itself [7-9]. Some authors state that the influence of exercise on brain functioning might be related to the human evolutionary process, since physical activity is associated with survival. It has been suggested that individuals who exercise might show a biological advantage over sedentary individuals [4]. Indeed, exercise is related to enhanced cognitive functioning and brain plasticity $[10,11]$. Although there is an increasing interest in the mechanisms supporting the positive effects of exercise on mental health, clinical evidence is still very limited.

\section{KARGER \\ Fax +4161306 1234 E-Mail karger@karger.ch} www.karger.com
Andréa Camaz Deslandes

Center for Alzheimer Disease and Related Disorders, Institute of Psychiatry

Universidade Federal do Rio de Janeiro, Rua Sylvio da Rocha Pollis 300, Casa 02

Recreio dos Bandeirantes 22793.395, Rio de Janeiro, RJ (Brazil)

Tel. +55 217896 9778, Fax +55 213328 5020, E-Mail adeslandes@ufrj.br 
Table 1. Summary of physical exercise interventions for elderly patients with major depressive disorder (MDD)

\begin{tabular}{|c|c|c|c|c|c|c|c|}
\hline Reference & Sample & Age, years & $\begin{array}{l}\text { Diagnostic } \\
\text { criteria }\end{array}$ & $\begin{array}{l}\text { Type of } \\
\text { exercise }\end{array}$ & $\begin{array}{l}\text { Intervention } \\
\text { duration }\end{array}$ & Primary outcomes & $\begin{array}{l}\text { Exercise group } \\
\text { improvement }\end{array}$ \\
\hline $\begin{array}{l}\text { Singh } \\
\text { et al. }{ }^{* *}[24]\end{array}$ & $\begin{array}{l}16 \mathrm{E} \\
16 \mathrm{C}\end{array}$ & $71.3 \pm 1.2$ & DSM-IV & ST & 20 weeks & BDI, HDRS, SF36 & BDI, HDRS, SF36 \\
\hline $\begin{array}{l}\text { Blumenthal } \\
\text { et al.* [20] }\end{array}$ & $\begin{array}{l}41 \mathrm{M} \text { (sertraline) } \\
39 \mathrm{E} \\
44 \mathrm{M}+\mathrm{E}\end{array}$ & $57 \pm 6.5$ & DSM-IV & AT & 16 weeks & BDI, HDRS & BDI, HDRS \\
\hline $\begin{array}{l}\text { Babyak } \\
\text { et al.* }[21]\end{array}$ & $\begin{array}{l}41 \mathrm{M} \text { (sertraline) } \\
39 \mathrm{E} \\
44 \mathrm{M}+\mathrm{E}\end{array}$ & $57 \pm 6.5$ & DSM-IV & AT & $\begin{array}{l}16 \text {-week } \\
\text { follow-up } \\
10 \text { months }\end{array}$ & BDI, HDRS & $\begin{array}{l}\text { Lower rates of } \\
\text { depression (clini- } \\
\text { cal diagnostic) }\end{array}$ \\
\hline $\begin{array}{l}\text { Singh } \\
\text { et al. }{ }^{* *}[25]\end{array}$ & $\begin{array}{l}15 \mathrm{E} \\
14 \mathrm{C}\end{array}$ & $71 \pm 2.0$ & DSM-IV & ST & $\begin{array}{l}20 \text {-week } \\
\text { follow-up } \\
26 \text { months }\end{array}$ & BDI, PGMS & BDI, PGMS \\
\hline $\begin{array}{l}\text { Herman } \\
\text { et al.* [22] }\end{array}$ & $\begin{array}{l}48 \mathrm{M} \text { (sertraline) } \\
53 \mathrm{E} \\
55 \mathrm{M}+\mathrm{E}\end{array}$ & $56.72 \pm 6.45$ & DSM-IV & AT & 16 weeks & $\begin{array}{l}\text { Dropout } \\
\text { remission (HDRS) }\end{array}$ & $\begin{array}{l}\text { Low dropout } \\
\text { (NS) }\end{array}$ \\
\hline $\begin{array}{l}\text { Mather } \\
\text { et al. [23] }\end{array}$ & $\begin{array}{l}42 \mathrm{E} \\
43 \mathrm{C}\end{array}$ & $\begin{array}{l}63 \\
65\end{array}$ & ICD-10 & AT & 10 weeks & HDRS, GDS & HDRS, GDS \\
\hline $\begin{array}{l}\text { Singh } \\
\text { et al. [26] }\end{array}$ & $\begin{array}{l}18 \mathrm{E} \text { (high intensity) } \\
17 \mathrm{E} \text { (low intensity) } \\
19 \text { control }\end{array}$ & $\begin{array}{l}69 \pm 5 \\
70 \pm 7 \\
69 \pm 7\end{array}$ & DSM-IV & ST & 8 weeks & HDRS, GDS & HDRS, GDS \\
\hline $\begin{array}{l}\text { Blumenthal } \\
\text { et al. [7] }\end{array}$ & $\begin{array}{l}53 \mathrm{E} \text { (home-based) } \\
51 \mathrm{E} \text { (supervised) } \\
49 \mathrm{M} \text { (sertraline) } \\
49 \text { placebo }\end{array}$ & $52 \pm 8$ & DSM-IV & AT & 16 weeks & HDRS & HDRS \\
\hline
\end{tabular}

$\mathrm{ST}=$ Strength training; $\mathrm{AT}=$ aerobic training; Group: $\mathrm{E}=$ exercise; $\mathrm{C}=$ control; $\mathrm{M}=$ medication. Depression rating scales: HDRS = Hamilton Depression Rating Scale; BDI = Beck Depressive Inventory; GDS = Geriatric Depressive Scale; DSM-IV = Diagnostic and Statistical Manual for Mental Disorders. ${ }^{*}$ and ${ }^{* *}=$ Same initial sample; NS = not significant between groups; SF36 = 36 Item Short Form Health Survey; PGMS = Philadelphia Geriatric Center Morale Scale; ICD-10 = International Statistical Classification of Diseases and Related Health Problems.

This revision, which focuses on the relationship between exercise and mental health, is divided into: (1) clinical studies that investigated the effect of exercise as a non-pharmacological treatment of mental illness, and (2) studies that hypothesized a neurophysiological pathway to explain the relationship between exercise and mental health.

\section{Method}

A computer search of PubMed and IsiWeb was conducted using a combination of the key words exercise, physical activity, and elderly with the specific mental disorder (major depression, Alzheimer's disease, Parkinson's disease). Articles that did not specify methods of clinical diagnosis and that did not measure effects of exercise were excluded. Also, studies that measured other comorbid conditions were excluded. After all exclusions, the final result comprised 32 articles. They are presented in table 1 (8 articles), table 2 (8 articles) and table 3 (16 articles). The other studies referenced in this review contribute to the understanding of the mechanism of action of exercise related to maintaining a healthy brain.

\section{Mental Health and Exercise: Clinical Evidences in Elderly Subjects}

\section{Physical Exercise and Major Depression}

A recent study has shown the overall prevalence of depression in the elderly to be $22 \%$, and that a sedentary 
Table 2. Summary of physical exercise interventions for elderly patients with Alzheimer's disease

\begin{tabular}{|c|c|c|c|c|c|c|}
\hline Reference & Sample & Age & Type of exercise & $\begin{array}{l}\text { Intervention } \\
\text { duration }\end{array}$ & Primary outcomes & $\begin{array}{l}\text { Exercise group } \\
\text { improvement }\end{array}$ \\
\hline $\begin{array}{l}\text { Palleschi } \\
\text { et al. [39] }\end{array}$ & $15 \mathrm{E}$ & $74 \pm 1.5$ & aerobic & 3 months & $\begin{array}{l}\text { MMSE, attentional } \\
\text { and verbal tests }\end{array}$ & $\begin{array}{l}\text { MMSE, attentional } \\
\text { and verbal tests }\end{array}$ \\
\hline $\begin{array}{l}\text { Arkin } \\
{[36]}\end{array}$ & $24 \mathrm{E}$ & $78.8 \pm 8.0$ & $\begin{array}{l}\text { aerobic, flexibility, } \\
\text { strength and balance }\end{array}$ & $\begin{array}{l}\text { at least } \\
1 \text { year }\end{array}$ & $\begin{array}{l}\text { strength and aerobic } \\
\text { capacity, GDS }\end{array}$ & $\begin{array}{l}\text { strength and } \\
\text { aerobic capacity }\end{array}$ \\
\hline $\begin{array}{l}\text { Teri } \\
\text { et al. [39] }\end{array}$ & $\begin{array}{l}76 \mathrm{E} \\
77 \mathrm{C}\end{array}$ & $\begin{array}{l}78 \pm 6 \\
78 \pm 8\end{array}$ & $\begin{array}{l}\text { aerobic, flexibility, } \\
\text { strength and balance }\end{array}$ & 3 months & $\begin{array}{l}\text { SF36, SIP, } \\
\text { HDRS, CSDD }\end{array}$ & $\begin{array}{l}\text { SF36, CSDD } \\
\text { HDRS }\end{array}$ \\
\hline $\begin{array}{l}\text { Mahendra } \\
\text { and Arkin [40] }\end{array}$ & $24 \mathrm{E}$ & $78.8 \pm 8.0$ & $\begin{array}{l}\text { aerobic, flexibility, } \\
\text { strength and balance }\end{array}$ & $\begin{array}{l}\text { at least } \\
1 \text { year }\end{array}$ & $\begin{array}{l}\text { strength and aerobic } \\
\text { capacity, GDS, } \\
\text { caregiver evaluation }\end{array}$ & $\begin{array}{l}\text { strength, aerobic capacity, } \\
\text { caregiver evaluation }\end{array}$ \\
\hline $\begin{array}{l}\text { Rolland } \\
\text { et al. [8] }\end{array}$ & $\begin{array}{l}67 \mathrm{E} \\
67 \mathrm{C}\end{array}$ & $\begin{array}{l}82.8 \pm 7.8 \\
83.1 \pm 7\end{array}$ & $\begin{array}{l}\text { aerobic, flexibility, } \\
\text { strength and balance }\end{array}$ & 12 months & Katz ADLs & Restrain ADL decline \\
\hline $\begin{array}{l}\text { Williams and } \\
\text { Tappen [34] }\end{array}$ & $\begin{array}{l}30 \mathrm{E}(\mathrm{sw}) \\
31 \mathrm{E}(\mathrm{ce}) \\
29 \mathrm{C}\end{array}$ & $88 \pm 6.32$ & $\begin{array}{l}\text { aerobic, flexibility, } \\
\text { strength and balance }\end{array}$ & 16 weeks & $\begin{array}{l}\text { DMAS, CSDD } \\
\text { AMS, OAS }\end{array}$ & $\begin{array}{l}\text { DMAS, CSDD } \\
\text { AMS, OAS }\end{array}$ \\
\hline Arkin [37] & $24 \mathrm{E}$ & $78.8 \pm 8.0$ & $\begin{array}{l}\text { aerobic, flexibility, } \\
\text { strength and balance }\end{array}$ & $\begin{array}{l}\text { at least } \\
1 \text { year }\end{array}$ & $\begin{array}{l}\text { MMSE, CDR, CERAD, } \\
\text { ABCD, WAIS-R }\end{array}$ & $\begin{array}{l}\text { MMSE, ABCD } \\
\text { WAIS-R comprehension }\end{array}$ \\
\hline $\begin{array}{l}\text { Williams and } \\
\text { Tappen [35] }\end{array}$ & $\begin{array}{l}16 \mathrm{E}(\mathrm{sw}) \\
17 \mathrm{E}(\mathrm{ce}) \\
12 \mathrm{C}\end{array}$ & $87.9 \pm 5.95$ & $\begin{array}{l}\text { aerobic, flexibility, } \\
\text { strength and balance }\end{array}$ & 16 weeks & $\begin{array}{l}\text { DMAS, CSDD } \\
\text { AMS, OAS }\end{array}$ & $\begin{array}{l}\text { DMAS, CSDD } \\
\text { AMS, OAS }\end{array}$ \\
\hline
\end{tabular}

ADLs = Activities of daily living; SF36 = 36-Item Short-Form Health Surveys; ABCD = Arizona Battery for Communication Disorders of Dementia; SIP = Sickness Impact Profile Mobility Subscale; DMAS = Dementia Mood Assessment Scale; CSDD = Cornell Scale for Depression in Dementia; AMS = Alzheimer Mood Scale; OAS = Observed Affect Scale; HDRS = Hamilton Depression Rating Scale; $\mathrm{E}=$ exercise; $\mathrm{C}$ = control; $\mathrm{sw}=$ supervised walking; $\mathrm{ce}=$ comprehensive exercise; MMSE = Mini-Mental State Examination; $\mathrm{CDR}=$ Clinical Dementia Rating; WAIS-R = Wechsler Adult Intelligence Test-Revised.

lifestyle is significantly correlated to depression morbidity [12]. Dunn et al. [13] showed that only 37 studies have studied exercise in major depressed (MDD) patients, out of a thousand papers on the issue. Reviews have suggested that exercise is an effective treatment for depression [14-17]. Other studies have also examined the effect of physical exercise on the prevention of depression $[18,19]$. Despite the fact that data on elderly patients are even scarcer, investigations have shown an inverse relationship between aerobic [7, 20-23] and strength training [24-26] and depression in the elderly (table 1). The efficacy of these interventions is influenced by diagnosis, intensity of exercise, and instruments used to evaluate response $[13,27]$. For example, aerobic exercise at an intensity consistent with public health recommendations can be regarded as an effective treatment of mild and moderate MDD. On the other hand, the effects of low-intensity exercise are comparable to placebo effects [27]. In a recent study, Blumenthal et al. [7] evaluated MDD patients with different treatments, namely sertraline, placebo, homebased exercise, and supervised exercise. Although the authors observed a higher remission rate with sertraline (47\%) and exercise (45\%), placebo response was also high, suggesting that a considerable portion of therapeutic response is also determined by the attention provided to the patient and to his/her own expectations regarding the treatment. Overall, there is little evidence for a possible dose-response effect of exercise on major depression.

\section{Physical Exercise and Alzheimer's Disease}

Although epidemiological studies have associated exercise with reduced risk to develop Alzheimer's disease (AD), the biological bases of such benefits remain inconclusive [28]. AD, a neurodegenerative disease, is characterized by the formation of $\beta$-amyloid plaques, neuronal loss in the hippocampus, reduced cholinergic function 
Table 3. Summary of physical exercise interventions for elderly patients with Parkinson's disease

\begin{tabular}{|c|c|c|c|c|c|c|}
\hline Reference & Sample & Age & Type of exercise & $\begin{array}{l}\text { Interven- } \\
\text { tion dura- } \\
\text { tion, weeks }\end{array}$ & Primary outcomes & $\begin{array}{l}\text { Exercise group } \\
\text { improvement }\end{array}$ \\
\hline $\begin{array}{l}\text { Comella } \\
\text { et al. [51] }\end{array}$ & $\begin{array}{l}18 \mathrm{E} \\
18 \mathrm{C}\end{array}$ & 66.8 & $\begin{array}{l}\text { general exercise } \\
\text { and PT }\end{array}$ & 4 & UPDRS & UPDRS \\
\hline $\begin{array}{l}\text { Schenkman } \\
\text { et al. [50] }\end{array}$ & $\begin{array}{l}23 \mathrm{E} \\
23 \mathrm{C}\end{array}$ & $55-84$ & individual flexibility & 10 & $\begin{array}{l}\text { spinal flexibility and } \\
\text { physical performance }\end{array}$ & $\begin{array}{l}\text { functional reach and } \\
\text { spinal flexibility }\end{array}$ \\
\hline $\begin{array}{l}\text { Reuter } \\
\text { et al. [49] }\end{array}$ & $16 \mathrm{E}$ & $65.4 \pm 5.9$ & $\begin{array}{l}\text { combined: aerobic gait, } \\
\text { flexibility, strength }\end{array}$ & 14 & $\begin{array}{l}\text { UPDRS, MMSE, BTM } \\
\text { CURS, AMQZ, SIP }\end{array}$ & $\begin{array}{l}\text { UPDRS, BTM and } \\
\text { CURS }\end{array}$ \\
\hline $\begin{array}{l}\text { Baatile } \\
\text { et al. [48] }\end{array}$ & $6 \mathrm{E}$ & $72.7 \pm 3.7$ & pole striding & 8 & UPDRS; PDQ-39 & ADLs \\
\hline $\begin{array}{l}\text { Niewboer } \\
\text { et al. [47] }\end{array}$ & $33 \mathrm{E}$ & 66.2 & functional training & 6 & UPDRS, activity scale score & activity scale score \\
\hline $\begin{array}{l}\text { Bergen } \\
\text { et al. [46] }\end{array}$ & $\begin{array}{l}4 \mathrm{E} \\
4 \mathrm{C}\end{array}$ & $\begin{array}{l}56.8 \pm 6.5 \\
63.5 \pm 9.2\end{array}$ & aerobic & 16 & $\begin{array}{l}\text { movement initiation, } \\
\mathrm{VO}_{2} \text { peak }\end{array}$ & $\begin{array}{l}\text { movement initiation } \\
\mathrm{VO}_{2} \text { peak }\end{array}$ \\
\hline $\begin{array}{l}\text { Hirsch } \\
\text { et al. [9] }\end{array}$ & $\begin{array}{l}9 \mathrm{E}(\mathrm{B}) \\
6 \mathrm{E}(\mathrm{S}+\mathrm{B})\end{array}$ & $\begin{array}{l}75.1 \pm 1.8 \\
70.8 \pm 2.8\end{array}$ & balance and strength & 10 & SOT, strength & strength, gait \\
\hline $\begin{array}{l}\text { Lun } \\
\text { et al. [52] }\end{array}$ & $\begin{array}{l}8 \mathrm{E} \text { (Home) } \\
11 \mathrm{E}(\mathrm{PT})\end{array}$ & $65 \pm 8$ & $\begin{array}{l}\text { balance, flexibility } \\
\text { and strength }\end{array}$ & 8 & $\begin{array}{l}\text { UPDRS total and motor } \\
\text { TUG, BBS, ABC scale }\end{array}$ & UPDRS motor \\
\hline $\begin{array}{l}\text { Protas } \\
\text { et al. [54] }\end{array}$ & $\begin{array}{l}9 \mathrm{E} \\
9 \mathrm{C}\end{array}$ & $\begin{array}{l}71.3 \pm 7.4 \\
73.7 \pm 8.5\end{array}$ & gait and step training & 8 & $\begin{array}{l}\text { reduce in falls, increase } \\
\text { in steps and gait }\end{array}$ & $\begin{array}{l}\text { reduce in falls, increase } \\
\text { in steps and gait }\end{array}$ \\
\hline $\begin{array}{l}\text { Miyai } \\
\text { et al. [45] }\end{array}$ & $\begin{array}{l}11 \mathrm{E}(\mathrm{BWSTT}) \\
9 \mathrm{E}(\mathrm{PT})\end{array}$ & $\begin{array}{l}69.5 \pm 1.9 \\
69.8 \pm 1.5\end{array}$ & BWSTT and PT & 4 & UPDRS, ambulation speed & $\begin{array}{l}\text { ambulation speed and } \\
\text { number of steps }\end{array}$ \\
\hline $\begin{array}{l}\text { Burini } \\
\text { et al. [44] }\end{array}$ & $22 \mathrm{E}$ & $65.2 \pm 6.5$ & aerobic and qigong & 14 & $\begin{array}{l}\text { UPDRS, PDQ39, 6-min } \\
\text { walk, BDI, BD'S }\end{array}$ & $\begin{array}{l}6 \text { min walk, } \mathrm{VO}_{2 \max } \\
\text { double product peak }\end{array}$ \\
\hline $\begin{array}{l}\text { Dibble } \\
\text { et al. [56] }\end{array}$ & $\begin{array}{r}10 \mathrm{E} \\
9 \mathrm{C}\end{array}$ & $\begin{array}{l}64.3 \pm 9.6 \\
67.0 \pm 10.2\end{array}$ & eccentric resistance & 12 & $\begin{array}{l}\text { mobility, muscle force, } \\
\text { quadriceps muscle volume }\end{array}$ & $\begin{array}{l}\text { mobility, muscle force, } \\
\text { quadriceps muscle } \\
\text { volume }\end{array}$ \\
\hline $\begin{array}{l}\text { De Paula } \\
\text { et al. [55] }\end{array}$ & $20 \mathrm{E}$ & $61.5 \pm 9.8$ & $\begin{array}{l}\text { aerobic, strength and } \\
\text { flexibility }\end{array}$ & 12 & NHP & NHP \\
\hline $\begin{array}{l}\text { Ashburn } \\
\text { et al. [53] }\end{array}$ & $\begin{array}{l}65 \mathrm{E} \\
65 \mathrm{C}\end{array}$ & $\begin{array}{l}72.7 \pm 9.6 \\
71.6 \pm 8.8\end{array}$ & $\begin{array}{l}\text { strength, balance and } \\
\text { aerobic }\end{array}$ & 6 & $\begin{array}{l}\text { BBT, SAS, QoL } \\
\text { functional reach }\end{array}$ & functional reach, QoL \\
\hline $\begin{array}{l}\text { Herman } \\
\text { et al. [43] }\end{array}$ & $9 \mathrm{E}$ & $70 \pm 6.8$ & aerobic & 6 & $\begin{array}{l}\text { UPDRS, PDQ39, SPPB, } \\
\text { gait speed }\end{array}$ & $\begin{array}{l}\text { PDQ39, UPDRS SPPB, } \\
\text { gait speed }\end{array}$ \\
\hline $\begin{array}{l}\text { Cakit } \\
\text { et al. [42] }\end{array}$ & $\begin{array}{l}21 \mathrm{E} \\
10 \mathrm{C}\end{array}$ & $71.8 \pm 6.4$ & $\begin{array}{l}\text { speed-dependent } \\
\text { treadmill }\end{array}$ & 8 & $\begin{array}{l}\text { BBT, DGI, FES walking } \\
\text { distance }\end{array}$ & $\begin{array}{l}\text { BBT, DGI, FES walking } \\
\text { distance }\end{array}$ \\
\hline
\end{tabular}

BWSTT = Body weight-supported treadmill training; DGI = Dynamic Gait Index; FES = Falls Efficacy Scale; BBT = Berg Balance Test; Qigong = Chinese physiotherapy approach; MMSE = Mini-Mental State Examination; TUG = time to up and go; BD'S = Brown's Disability Scale; $\mathrm{E}=$ exercise; $\mathrm{C}=$ control; $\mathrm{PT}$ = physiotherapy; $\mathrm{B}=$ balance; $\mathrm{S}=$ strength; $\mathrm{QoL}=$ quality of life thermometer; $\mathrm{BBS}=$ Berg Balance Scale; UPDRS = Unified Parkinson's Disease Rating Scale; PDQ39 = 39-Item Parkinson's Disease Questionnaire; AMQZ = Adjective Mood Questionnaire of Zeersen; ABC Scale = Activities-Specific Balance Confidence Scale; SAS = Self-Assessment Parkinson's Disease Disability Scale; NHP = Nottingham Health Profile; BDI = Beck Depression Inventory; SPPB = Short Physical Performance Battery; SIP= Sickness Impact Profile; SOT = Sensory Orientation Test; BMT = Basic Motor Test; CURS = Columbia University Rating Scale. 
and cognitive deterioration. Environmental stimuli along with genetic factors are thought to influence the onset of the disease. Among the lifestyle changes associated with $\mathrm{AD}$ prevention, exercise is seen as one of the most important ones [29]. Several studies have reported the relationship between physical activity and reduced incidence of dementia or cognitive deterioration [29-32]. A recent analysis of 10 studies investigating the effects of motor intervention treatments for subjects with dementia suggested positive effects of this non-pharmacological approach [33]. The efficacy of motor intervention was confirmed in affective status, psychosocial function, physical health and function, and caregiver distress. In another study, Teri et al. [31] observed that daily $30 \mathrm{~min}$ of physical training (aerobic, flexibility and strength) reduced the number of hospitalizations in $153 \mathrm{AD}$ patients. It also decreased depressive symptoms and improved quality of life. Rolland et al. [8] evaluated 134 patients and demonstrated that, after a year of exercise intervention, the exercise group improved quality of life, as compared to the sedentary group. Other studies showed significant mood improvement in older adults with $\mathrm{AD}[34,35]$. In a recent study, Williams and Tappen [34] observed an antidepressant effect of exercise in severe AD. However, such investigations are still scarce and very little is known about the efficiency of exercise as a protective factor in $\mathrm{AD}[31,34-$ 40] (table 2).

\section{Physical Exercise and Parkinson's Disease}

Parkinson's disease (PD) is associated with genetic, environmental, and behavioral factors. Motor alterations are expressed as tremor, rigidity and hypokinesia, as well as posture and balance changes [41]. Such alterations are directly associated with falls and fatigue experienced by the patients. Exercise might help by protecting against the disease as well as an adjunctive treatment [42-57]. Epidemiological studies have suggested that exercise is related to a reduced risk of developing $\mathrm{PD}$. Also, clinical studies have investigated the effectiveness of exercise, mainly focusing on motor performance, gait, and activities of daily living (ADLs) [58, 59]. Thacker et al. [57] have demonstrated that the intensity of exercise might influence the neuroprotective response. Higher intensities of exercise would be positively related to a protective factor, when compared to lower intensities. Goede et al. [59] observed that physical activity is significantly beneficial to PD patients, improving their quality of life, walking skills, and reducing neurological symptoms. In fact, improving functional capabilities as a consequence of strength and balance training might positively influence their independence and quality of life, not necessarily because of neurochemical alterations. Therefore, strength improvement also has an essential role in daily activities. Parkinsonians (idiopathic) who accomplished a 10-week strength and balance program developed strength and reduced the number of falls [9]. Although somewhat limited, evidence suggests that exercise training is beneficial to patients with PD, especially in functional capacity and ADLs improvement (table 3).

\section{Neurophysiological Hypothesis}

The protective effect of exercise could be explained by the hormesis theory, in which low doses of toxins and/or radiation can exert beneficial effects in organisms [60]. Radak et al. [61, 62] extended the hormesis theory to include reactive oxygen species (ROS), suggesting that the beneficial effects of regular exercise are partly based on its ability to generate ROS. Exercise-induced ROS production plays a role in the induction of antioxidants, DNA repair and protein-degrading enzymes, resulting in decreases in the incidence of oxidative stress-related diseases. Exercise would, therefore, increase the circulation of the same proinflammatory cytokines that are normally upregulated during a stress response. However, exercise may also upregulate anti-inflammatory cytokines, and with time, increase the immune system threshold for stress [63].

Exercise increases the release and synthesis of several neurotrophic factors related to better cognitive functioning, neurogenesis, angiogenesis and plasticity. The brainderived neurotrophic factor (BDNF) and the insulin-like growth factor (IGF-1) are the factors that have been investigated the most. Animal research supports the idea that BDNF is essential for hippocampal functioning, synaptic plasticity, learning, and modulation of depression $[5,64,65]$. Studies have shown that exercise elevates the level of BDNF in the rat hippocampus, acting just like a regular antidepressive drug [66]. Winter et al. [67] observed an increase in BDNF in humans running at a high intensity (blood lactate level $>10 \mathrm{mmol} / \mathrm{l}$ ). Moreover, the authors showed that exercise accelerates learning. The IGF-1 is another neurotrophic factor correlated with cognitive improvement. IGF-1 is also correlated with neurogenesis, since its release starts several processes related to the proliferation of progenitor cells in the subgranular zone. Exercise increases IGF-1 levels, which are diminished in elderly adults with poor cognitive performance [68]. Since strength training increases testosterone and 
IGF-1 levels, some authors argue that strength training might have an advantage over cardiovascular training. For example, Cassilhas et al. [69] observed improved cognitive functioning and higher IGF-1 levels in a group of elderly individuals after 6 months of strength training. Nottebohm [70] hypothesized that testosterone is the key to higher BDNF levels. In the brain, testosterone is aromatized in estradiol, and several studies have showed the correlation between estradiol and cognitive and mood aspects. Another important aspect is the regulation of the amyloid levels by IGF-1, since IGF-1 is inversely correlated with the $\beta$-amyloid peptide.

In addition to BDNF and IGF-1, exercise also regulates the expression of vascular endothelial growth factor (VEGF). VEGF regulates endothelial cell proliferation and angiogenesis, but also has neurotrophic, neuroprotective, and neurogenic effects. While IGF-1 and BDNF mediate behavioral improvements as a consequence of exercise, the interactive effects of IGF-1 and VEGF seem to coordinate exercise-induced neurogenesis and angiogenesis. Exercise-induced angiogenesis is associated with an increase in brain VEGF [65]. Pereira et al. [71] observed an in vivo correlation of exercise-induced neurogenesis and angiogenesis in the adult dentate gyrus, which was based on an increase of cerebral blood volume in this specific area.

Stress, depression and aging would decrease neurotrophic expression and neurogenesis in the brain, and both antidepressants and exercise would reverse these effects [5, 65]. Kempermann [72] proposed that major depression might result from a disturbance in neuronal plasticity and adult hippocampal neurogenesis. Neurogenesis in the adult hippocampus might improve cognitive processes (e.g., memory functioning) and treatment of several psychiatric diseases (e.g., depression). Voluntary exercise enhanced neurogenesis in the dentate gyrus of the adult mouse [73]. Stemming from these findings, the focus on the relationship between exercise and mental health has taken a new direction: neurogenesis in the adult human brain.

Exercise increases several neurotransmitters, such as serotonin (5-HT), dopamine (D), acetylcholine (ACh) and norepinephrine (NE). Moreover, exercise increases the activity of some subtypes of receptors for neurotransmitters changing the cortical/subcortical activity (for a review, see Sarbadhikari and Saha [74]). Winter et al. [67] observed a strong increase in peripheral catecholamine plasma levels (NE, 5-HT and D) after intense physical exercise in humans, and associated it to learning and memory improvements. However, peripheral catechol- amines do not cross the blood-brain barrier. A possible mechanism, then, is the calcium-calmodulin system, since exercise leads to increased serum calcium levels, and calcium is transported to the brain. This, in turn, enhances brain dopamine synthesis through a calmodulin-dependent system, and increases dopamine levels. In addition, exercise releases anandamide, which in turn, increases the dopamine release. Sparling et al. [75] reported the first evidence that exercise at a moderate intensity activates the endocannabinoid system. They showed elevated plasma anandamide levels in runners and cyclists when compared to sedentary controls. The analgesia, sedation, anxiolysis, and a sense of well-being with physical activity would be related to this neurophysiological pathway [76]. This mechanism seems to better explain the analgesic effects of exercise rather than the endorphin hypothesis. Plasmatic endorphin levels do not necessarily represent levels in the brain, due to the blockade of the blood-brain barrier. Hence, studies have shown that the endorphin release only occurs at high exercise intensities. A recent study showed in vivo evidence that release of endogenous opioids occurs in frontolimbic brain regions after exercise, which has been related to the level of euphoria after running [77].

Cerebral activity is positively correlated with an increase in oxygen and glucose uptake and with an increase in regional cerebral blood flow (CBF). Exercise is related to an increase in CBF in several cortical and subcortical areas [78]. Adenine nucleotides play a major role in the local control of CBF. In 1979, Forrester [79] proposed that circulating nucleotides and derivatives released from active skeletal muscle achieve levels in the arterial blood that would affect cerebral metabolism, by a system of 'metabolic communication' in the body mediated by circulating purine compounds. The levels of adenosine triphosphate (ATP), a potent vasodilator, increase during exercise and could be a mechanism involved in $\mathrm{CBF}$ regulation. Cerebral perfusion is also dependent on nitric oxide (NO), and physical activity upregulates endothelial $\mathrm{NO}$ synthesis and improves angiogenesis and $\mathrm{CBF}$ [80]. Moreover, exercise increases the production of VEGF which is believed to be the primary growth factor associated with capillary formation in the developing brain $[5,65]$.

\section{Conclusion}

Although exercise improves quality of life, prevents falls, increases balance, strength, and improves ADLs, the efficacy of an exercise intervention after the onset of 
the disease is not commonly assessed and, therefore, needs to be investigated with randomized clinical trials. Neuropsychological aspects, invasive measurements (e.g., neurotrophic factors, neurotransmitters, hormones), neuroimaging studies, or some physiological markers associated with clinical parameters could help elucidate the potential role of exercise as a non-pharmacological treatment of mental disorders. Our review presents recent findings in clinical and animal investigations concerning the effects of exercise on general brain func- tioning. Although this is a promising research topic, the study of the real effects of exercise as an adjunctive treatment of mental illness still has a long way to go.

\section{Role of Funding Source}

Funding for this study came from FAPERJ. The funding sources had no further role in study design, the collection, analysis and interpretation of the data, in the writing of the report, and in the decision to submit the paper for publication.

\section{References}

$\checkmark 1$ Hillman CH, Erickson KI, Kramer AF: Be smart, exercise your heart: exercise effects on brain and cognition. Nature 2008;9:5865.

-2 Kramer AF, Colcombe SJ, McAuley E, et al: Fitness, aging and neurocognitive function. Neurobiol Aging 2005;26(suppl):S124-S127.

$\checkmark 3$ Stein D, Collins M, Daniels W, et al: Mind and Muscle: the cognitive-affective neuroscience of exercise. CNS Spectrum 2007;12: 19-22.

4 Vaynman S, Gomez-Pinilla F: Revenge of the 'sit': how lifestyle impacts neuronal and cognitive health through molecular systems that interface energy metabolism with neuronal plasticity. J Neurosci Res 2006;84:699-715.

$\checkmark 5$ Duman R: Neurotrophic factors and regulation of mood: role of exercise, diet and metabolism. Neurobiol Aging 2005;26(suppl): S88-S93.

-6 Dishman RK, Berthoud HR, Booth FW, et al: Neurobiology of exercises. Obesity 2006;14: 345-356

7 Blumenthal JA, Babyak MA, Doraiswamy MP, et al: Exercise and pharmacotherapy in the treatment of major depressive disorder. Psychosom Med 2007;69:587-596.

$>8$ Rolland Y, Pillard F, Klapouszczak A, et al: Exercise program for nursing home residents with Alzheimer's disease: a 1-year randomized, controlled trial. J Am Geriatr Soc 2007;55:158-165.

-9 Hirsch M, Toole T, Maitland C, et al: The effects of balance training and high-intensity resistance training on persons with idiopathic Parkinson's disease. Phys Med Rehabil 2003;84:1109-1117.

-10 Colcombe SJ, Erickson SI, Scalf PE, et al: Aerobic exercise training increases brain volume in aging humans. J Gerontol Med Sci 2006;61:1166-1170

$\checkmark 11$ Kramer AF, Erickson SI: Effects of physical activity on cognition, well-being, and brain: humans interventions. Alzheimers Dement 2007;3:S45-S51.

- 12 Blay S, Andreoli S, Fillenbaum G, et al: Depression morbidity in later life: prevalence and correlates in a developing country. Am J Geriatr Psychiatry 2007;15:790-799.
13 Dunn A, Trivedi M, O’Neal H: Physical activity dose-response effects on outcomes of depression and anxiety. Med Sci Sports Exerc 2001;33:S587-S597.

14 Stathopoulou G, Powers M, Berry A, et al: Exercise interventions for mental health: a quantitative and qualitative review. Clin Psychol Sci Pract 2006;13:180-193.

15 Frazer CJ, Christensen H, Griffiths KM: Effectiveness of treatments for depression in older people. Med J Aust 2005; 182:627-632.

16 Craft L, Perna F: The benefits of exercise for the clinically depressed. Prim Care Companion J Clin Psychiatry 2004;6:104-111.

17 Moraes H, Deslandes A, Ferreira C, et al: O exercício físico no tratamento da depressão em idosos: revisão. Rev Psiquiatr RS 2007;29: 70-79.

18 Lampinen P, Heikkinen E: Reduced mobility and physical activity as predictors of depressive symptoms among community-dwelling older adults: an eight-year follow-up study. Aging Clin Exp Res 2003;15:205-211.

19 Strawbridge WJ, Deleger S, Roberts RE, et al: Physical activity reduces the risk of subsequent depression for older adults. Am J Epidemiol 2002;156:328-334.

20 Blumenthal JA, Babyak MA, Moore KA, et al: Effects of exercise training on older patients with major depression. Arch Intem Med 1999;159:2349-2356.

21 Babyak M, Blumenthal JA, Herman S, et al: Exercise treatment for major depression: maintenance of therapeutic benefit at 10 months. Psychosom Med 2000;62:633-638.

22 Herman S, Blumenthal JA, Babyak M, et al: Exercise therapy for depression in middleaged and older adults: predictors of early dropout and treatment failure. Health Psychol 2002;21:553-563.

-23 Mather AS, Rodriguez C, Guthrie MF, et al: Effects of exercise on depressive symptoms in older adults with poorly responsive depressive disorder: randomized controlled trial. Br J Psychiatry 2002;180:411-415.
24 Singh NA, Clements KM, Fiatarone MA: A randomized controlled trial of progressive resistance training in depressed elders. J Gerontol A Biol Sci Med Sci 1997;52:M27M35.

25 Singh N, Clements K, Singh M: The efficacy of exercise as a long-term antidepressant in elderly subjects: a randomized, controlled trial. J Gerontol A Biol Sci Med Sci 2001;56: M497-M504.

26 Singh N, Stavrinos TM, Scarbek Y, et al: A randomized controlled trial of high versus low intensity weight training versus general practitioner care for clinical depression in older adults. J Gerontol 2005;6:768-776

27 Dunn A, Trivedi M, Kampert J, et al: Exercise treatment for depression efficacy and dose response. Am J Prev Med 2005;28:1-8.

28 Wolf S, Kronenberg G, Lehmann K, et al: Cognitive and physical activity differently modulate disease progression in the amyloid precursor protein-23 model of Alzheimer's disease. Biol Psychiatry 2006;60:1314-1323.

29 Pope S, Shue V, Beck C: Will a healthy lifestyle help prevent Alzheimer's disease? Annu Rev Public Health 2003;24:111-132.

\$30 Colcombe S, Kramer AF: Fitness effects on the cognitive function of older adults: a meta-analytic study. Psychol Sci 2003;14: 125-130.

$>31$ Teri L, Gibbons LE, McCurry SM, et al: Exercise plus behavioral management in patients with Alzheimer disease: a randomized controlled trial. JAMA 2003;290:20152022.

32 Arcoverde C, Deslandes A, Rangel A, et al: Role of physical activity on the maintenance of cognition and activities of daily living in elderly with Alzheimer's disease. Arq Neuropsiquiatr 2008;66:323-327.

33 Christofoletti G, Oliani M, Gobbi S, et al: Effects of motor intervention in elderly patients with dementia. An analysis of randomized controlled trials. Top Geriatr Rehabil 2007;23:149-154.

34 Williams CL, Tappen RM: Effect of exercise on mood in nursing home residents with Alzheimer's disease. Am J Alzheimers Dis Other Demen 2007;22:389-397. 
-35 Williams CL, Tappen RM: Exercise training for depressed older adults with Alzheimer's disease. Aging Ment Health 2008;12:72-80.

- 36 Arkin SM: Student-led exercise sessions yield significant fitness gains for Alzheimer's patients. Am J Alzheimers Dis Other Demen 2003;18:159-170.

- 37 Arkin S: Language-enriched exercise plus socialization slows cognitive decline in Alzheimer's disease. Am J Alzheimers Dis Other Demen 2007;22:62-77.

-38 Heyn P: The effect of a multisensory exercise program on engagement, behavior, and selected physiological indexes in persons with dementia. Am J Alzheimers Dis Other Demen 2003;18:247-251.

39 Palleschi L, Vetta F, de Cennaro E, et al: Effect of aerobic training on the cognitive performance of elderly patients with senile dementia of Alzheimer type. Arch Gerontol Geriatr 1996;22(suppl 1):47-50.

40 Mahendra N, Arkin SM: Exercise and volunteer work: contexts for $\mathrm{AD}$ language and memory interventions. Semin Speech Lang 2004;25:151-167.

41 Hof P, Mobbs C: Functional Neurobiology of Aging. New York, Academic Press, 2001.

-42 Cakit BD, Saracoglu M, Genc H, et al: The effects of incremental speed-dependent treadmill training on postural instability and fear of falling in Parkinson's disease. Clin Rehabil 2007;21:698-705.

43 Herman T, Giladi N, Gruendlinger L, et al: Six weeks of intensive treadmill training improves gait and quality of life in patients with Parkinson's disease: a pilot study. Arch Phys Med Rehabil 2007;88:1154-1158.

-44 Burini D, Farabollini B, Iacucci S, et al: A randomised controlled cross-over trial of aerobic training versus Qigong in advanced Parkinson's disease. Eura Medicophys 2006; 42:231-238

45 Miyai I, Fujimoto Y, Ueda Y, et al: Treadmill training with body weight support: its effect on Parkinson's disease. Arch Phys Med Rehabil 2000;81:849-852.

-46 Bergen JL, Toole T, Elliott RG 3rd, et al: Aerobic exercise intervention improves aerobic capacity and movement initiation in Parkinson's disease patients. NeuroRehabilitation 2002;17:161-168.

47 Nieuwboer A, Kwakkel G, Rochester L, et al: Cueing training in the home improves gaitrelated mobility in Parkinson's disease: the RESCUE trial. J Neurol Neurosurg Psychiatry 2007;78:134-140.

48 Baatile J, Langbein WE, Weaver F, et al: Effect of exercise on perceived quality of life of individuals with Parkinson's disease. J Rehabil Res Dev 2000;37:529-534.

- 49 Reuter I, Engelhardt M, Stecker K, et al: Therapeutic value of exercise training in Parkinson's disease. Med Sci Sports Exerc 1999;31:1544-1549.
50 Schenkman M, Cutson TM, Kuchibhatla M, et al: Exercise to improve spinal flexibility and function for people with Parkinson's disease: a randomized, controlled trial. J Am Geriatr Soc 1998;46:1207-1216.

51 Comella CL, Stebbins GT, Brown-Toms N, et al: Physical therapy and Parkinson's disease: a controlled clinical trial. Neurology 1994 44:376-378.

52 Lun V, Pullan N, Labelle N, et al: Comparison of the effects of a self-supervised home exercise program with a physiotherapist-supervised exercise program on the motor symptoms of Parkinson's disease. Mov Disord 2005;20:971-975.

-53 Ashburn A, Fazakarley L, Ballinger C, et al: A randomised controlled trial of a home based exercise programme to reduce the risk of falling among people with Parkinson's disease. J Neurol Neurosurg Psychiatry 2007; 78:678-684

54 Protas EJ, Mitchell K, Williams A, et al: Gait and step training to reduce falls in Parkinson's disease. NeuroRehabilitation 2005;20: 183-190.

55 De Paula F, Teixeira-Salmela LF, Faria CD, et al: Impact of an exercise program on physical, emotional, and social aspects of quality of life of individuals with Parkinson's disease. Mov Disord 2006;21:1073-1077.

56 Dibble LE, Hale TF, Marcus RL, et al: Highintensity resistance training amplifies muscle hypertrophy and functional gains in persons with Parkinson's disease. Mov Disord 2006;21:1444-1452.

57 Thacker EL, Chen H, Patel AV, et al: Recreational physical activity and risk of Parkinson's disease. Mov Disord 2008;23:69-74.

58 Garber CE, Friedman JH: Effects of fatigue on physical activity and function in patients with Parkinson's disease. Neurology 2003; 60:1119-1124.

59 Goede CJ, Keus SH, Kwakkel G, et al: The effects of physical therapy in Parkinson's disease: a research synthesis. Arch Phys Med Rehabil 2001;82:509-515.

60 Stebbing AR: Hormesis: the stimulation of growth by low levels of inhibitors. Sci Total Environ 1982;22:213-234.

61 Radak Z, Chung HY, Goto S: Exercise and hormesis: oxidative stress-related adaptation for successful aging. Biogerontology 2005;6:71-75.

62 Radak Z, Chung HY, Koltai E, et al: Exercise, oxidative stress and hormesis. Ageing Res Rev 2008;7:34-42.

63 Zaldivar F, Wang-Rodriguez J, Nemet D, et al: Constitutive pro- and anti-inflammatory cytokine and growth factor response to exercise in leukocytes. J Appl Physiol 2006;100: 1124-1133.

64 Lie D, Song H, Colamarino S, et al: Neurogenesis in the adult brain: new strategies for central nervous system diseases. Annu Rev Pharmacol Toxicol 2004:44:399-421.
65 Cotman CW, Berchtold NC, Christie LA: Exercise builds brain health: key roles of growth factor cascades and inflammation. Trends Neurosci 2007;30:464-472.

-66 Russo-Neustadt A, Beard RC, Cotman CW: Exercise, antidepressant medications, and enhanced brain derived neurotrophic factor expression. Neuropsychopharmacology 1999;21:679-682.

67 Winter B, Breitenstein C, Mooren FC, et al: High impact running improves learning. Neurobiol Learn Mem 2007;87:597-609.

68 Landi F, Capoluongo E, Russo A, et al: Free insulin-like growth factor-I and cognitive function in older persons living in community. Growth Horm IGF Res 2007;17:58-66.

69 Cassilhas RC, Viana VA, Grassmann V, et al: The impact of resistance exercise on the cognitive function of the elderly. Med Sci Sports Exerc 2007;39:1401-1407.

70 Nottebohm F: Why are some neurons replaced in adult brain? J Neurosci 2002;22: 624-628

-71 Pereira A, Huddleston D, Brickman A, et al: An in vivo correlate of exercise-induced neurogenesis in the adult dentate gyrus. Proc Natl Acad Sci USA 2007;104:5638-5643.

72 Kempermann G: Regulation of adult hippocampal neurogenesis - implications for novel theories of major depression. Bipolar Disord 2002;4:17-33.

73 Van Praag H, Kempermann G, Gage FH: Running increases cell proliferation and neurogenesis in the adult mouse dentate gyrus. Nat Neurosci 1999;2:266-270.

74 Sarbadhikari SN, Saha AK: Moderate exercise and chronic stress produce counteractive effects on different areas of the brain by acting through various neurotransmitter receptor subtypes: a hypothesis. Theor Biol Med Model 2006;3:33.

-75 Sparling PB, Giuffrida A, Piomelli D, et al: Exercise activates the endocannabinoid system. Neuroreport 2003;14:2209-2211.

76 Dietrich A, McDaniel WF: Endocannabinoids and exercise. Br J Sports Med 2004;38: 536-541.

77 Boecker H, Sprenger T, Spilker ME, et al: The runner's high: opioidergic mechanisms in the human brain. Cereb Cortex 2008; 18 : 2523-2531.

78 Critchley HD, Corfield DR, Chandler MP, et al: Cerebral correlates of autonomic cardiovascular arousal: a functional neuroimaging investigation in humans. J Physiol 2000;523: 259-270.

79 Forrester T: Extracellular nucleotides in exercise: possible effect on brain metabolism. Physiologist 1979;22:50-58.

80 Gertz K, Priller J, Kronenberg G, et al: Physical activity improves long-term stroke outcome via endothelial nitric oxide synthasedependent augmentation of neovascularization and cerebral blood flow. Circ Res 2006;99:1132-1140. 